\title{
The Waves of Internal Migration in Russia
}

\author{
Salavat Abylkalikov \\ National Research University Higher School of Economics, Moscow, Russia \\ Email: abylkalikov@yandex.ru
}

\section{Doi:10.5901/ajis.2013.v2n9p572}

\begin{abstract}
For the several centuries the population of the European part of Russia has been migrating to the Eastern and North-Eastern peripheral regions of the vast country. The comfortable areas were colonized as well as the deserted ones with severe climate conditions. The cossacks were the first who populated new lands. Some decades after it the peasants followed such strategy. Forced migration of Gulag prisoners and convicts played an important role in migrations during the Soviet period (although the resettlement of prisoners were in pre-revolutionary times too). In the 2-nd half of 20-th century the internal migration in Russia experienced a dramatic change. Since then a massive escape from recently occupied lands has been observed. The fall of the Soviet Union has accelerated the return migrations. In the paper the basic patterns of internal migration in Russia are specified and analyzed on the data of Russian Censuses. Russian regions are also classified by their migration characteristics.
\end{abstract}

\section{Introduction}

The internal migrations in Russia had the wavy character: sometimes they shrank, and sometimes they overwhelmed more and more newly annexed territories. It had lasted for few centuries. However, lately migration waves had turned back.

The population of Russia was formed under the influence of migratory processes, somewhere very strong, and somewhere weak. The direction of migrations was also different - the arrival and the departure of the population. The information about the place of birth which one can find out from the population census informs about the lifetime migrations accomplished during the life. Moreover, as a rule, the census data demonstrates the high precision of the response on the question about the place of birth because it is clear to people. The drawback of this question is impossibility of defining of migrations number and exact date of moving, and also of returned migrants singling out.

The question about place of birth in Russian population censuses was posed in 1897, 1926, 1989, 2002 and 2010. The migratory questions were not posed at all in population censuses of 1937, 1939, 1959, non-informative questions about the duration and continuity of residence were asked in 1970 and 1979 (Moiseenko, 2004).

In total, the population censuses can be one of most important information sources about the population migration in the absence of the rich choice of other statistic sources of information about migratory movements of the population. The program of Russian censuses development for a number of reasons was planned in such a way that the only question "available" and remaining in few censuses was the question about the place of birth, necessary for the analysis of migrations.

\section{Typology of regions}

To characterize the process of population arrival to the region more reasonable to use the share of native of other regions in the constant population of the arrival region. There was made a typology on the basis of singing out indices of migration intensity, including few groups of regions:

- Recipients and strong recipients, more attractive regions for migrants. For example, Moscow can be referred to strong recipients.

- Scrubbing regions where the share so far rived and departed have comparable value, these regions often form "the buffer" between regions-donators and regions-recipients.

- Donators and strong donators which are "suppliers" of lifetime migrants. The part of the regions not only give but also actively accept migrants but several times fewer.

- Regions with low indices of arrived and departed refer to regions that can be considered as isolators. 


\section{Population census of 1897: from the abolishment of the serfdom to the opening up of outskirts}

In 1861 the important event took place in the history of Russian state - owing to the manifesto of the serfdom abolishment the major part of the country got freedom of movement for the first time for many centuries. The first AllRussian population census was carried out only after 36 years and it's impossible to ascertain how the serfdom abolishment favored intensification of lifetime migrations.

End of XIX-beginning of XX centuries was characterized by rapid growth of economics and agriculture. Exactly by this time the population of Russian towns has increased. Saint-Petersburg which was the capital numbered 1.2 millions people, Moscow - 1million. The largest cities became one of the most attractive places for the migration. So, there was $60.4 \%$ of lifetime migrants of total population in Saint-Petersburg. High percentage of migrants was noted in the largest cities of the empire, in Moscow, Warsaw, Odessa, Saratov, Kazan, Tula, Tomsk. The capital and the large cities attracted othodniks ${ }^{1}$ and those who moved there for the permanent dwelling.

After the reforms by Alexander II there was rapid population growth owing to the appearing of medicine and the introduction of elementary hygiene rules resulting in sharp reduction of death rate, especially infant mortality. The population growth in the conditions of appearing land deficit provoked necessity of either going off in search of a living or migrations. "Excesses" of rural population made their way to east provinces, to Siberia, Altai, Far East.

According to the data of 1897 population census, the major part of migrants was in Far East regions of the empire, especially located near the Pacific Ocean of Sakhalin and the Primorie Territory. These territories were annexed to Russia in XIX century and were the most colonized, and exiles and state convicts took active part in opening up of new possessions ${ }^{2}$. In such Far East provinces as Amur Oblast and Primorie Territory there were more migrants than the half of the population. The share of migrants was lower in Siberia than on Far East.

Yakutia, Central Asia, Transcaucasia, Dagestan province were less attractive for Russian Empire. Dagestan province almost didn't take part in migrational exchange with other territories. Black Earth Belt area, Volga region, VolgaVyatka region with an overflow of population actively gave population to the other provinces.

Thus, population census of 1897 fixed the important moments of migration history of the country - beginning of colonization of outlying districts of the empire mainly by natives of European part of the country. At the same time these censuses show that part of regions wasn't involved in migratory processes and Poland and Baltic regions developed rather independently from the rest of the country.

\section{Population census of 1926 - from Stolipin's reform to civil war}

At the turn of $X I X-X X$ centuries imperial government changed their politics on migration stimulation, which most actively proved itself during the realization of Stolipin's reforms ${ }^{1}$. Revolution and the following civil war, increasing urbanization by 1926 contributed to the strengthening of migration processes (Borodkin, Maksimov, 1993). External migrations which became more active during civil war in the form of emigration, almost completely stopped due to the total closing of the borders of young soviet state. The migration processes began to be carried out only in the external limits of the country (Politics of immigration, 2005).

Siberia replenished the population with migrants from Central Russia, Black Earth Belt area and Belorussia. Migrants from Siberia, Ukraine and Volga region moved to Far East, the stream from other regions of European Russia have decreased.

Urbanization became the most active process in the country; the percentage of migrants was higher $60 \%$ in large cities - in Moscow, Leningrad and in North Caucasian cities - Grozny and Vladikavkaz.

Census of 1926 was carrying out in the terms of devastation of postwar time. Besides the tendencies fixed in 1897 there were some new, appeared at the time of agrarian reform of imperial government since in the result of revolution, urbanization and rapid industrial development during the pre-revolutionary period and after civil war. At this period total migration activity of the population increased significantly almost 3 times.

\footnotetext{
${ }^{1}$ Othodniks - the temporary workers (mostly peasants) who come to work into other regions, as well as to Moscow and to St. Petersburg. A significant part of earnings they sent to the family. After they have accumulated enough money, they came back home.

${ }^{2}$ Since the reign of the Empress Elizabeth of Russia the death penalty in Russian Empire was replaced for the eternal servitude. The death penalty is applied only in cases of the treason.
} 


\section{Population census of 1989: the result of the soviet period migrations}

During pre-war period migration flows were directed to eastern regions of the country. Migration was connected with continuation of development of boundless spaces of Siberia and Far East, compulsory migrations (deportations, labor of prisoners, exile of wealthy peasants) contributed to this process. During the years of Great Patriotic War main migration flows were connected with evacuation and than with resettlement back (Politics of immigration, 2005).

From 1960-s migration flows changed their direction. During post-war period virgin lands campaign ${ }^{1}$ began with significant flows of migrants to Kazakhstan, south regions of Siberia, Far East and also to Volga region and Ural. The large flow of the specialists made its way to the industrialization of republics of Middle Asia and Transcaucasia: outflow of population from Transcaucasia and Siberia. In 1970-s due to the opening up of oil and gas fields migration flow to the Western Siberia regions and Russian North began to increase.

There was strong inflow of population to Moscow and Leningrad and also to the plain part of North Caucasus. The population was still arriving to the Far East. From the second part of 1980-s outflow from the North regions began and total migration activity also began to decrease, particularly due to the exhaustion of the migration potential of the rural settlement. The central and the south-western regions of the country accepted migrants (Rybakovsky, 1996).

\section{Population census of 2002 and 2010: from the collapse of the USSR to the market economics}

Introduction of market elements not long before collapse of the USSR and strong reduction of the quality of provision of northern cities and settlements, exhaustion of migration resource of the countryside resulted in decreasing of migration activity of the population. Domestic migration became external, armed conflicts in different parts of former Union caused flows of refugees and forced migrants going generally to Russia.

Together with opening of the external borders from far-abroad countries - China, Northern Korea, Vietnam. In the domestic migration the main flows were directed to the Center (especially to Moscow and the region) and South. Far East and many regions of Eastern Siberia began to lose population actively, more western territories of Siberia and Ural became to be characterized as scrubbing regime (Mkrtchyan, 2004).

After the collapse of Soviet Union and establishing of market economy in the country, there was increasing of regions number with migration outflow situated in Siberia as well in the Far East. At this time abrupt worsening of life quality took place in many regions with extreme environmental conditions which began to lose population. Such regions as Moscow, Saint-Petersburg and Western Siberia on the contrary continued to accept population from other region and former union republics.

\section{Evolution lifetime migrations directions in $1897-2010$}

In 1897 few zones distinguished clearly, giving and accepting. So, it's possible to single out cluster of regions of European part of Russia (see figure 1), which were the main source of lifetime migrants and Siberia and Far Eastern regions (except Yakutia and Transbaikalia), to which these flows were directing. The capitals and its regions are worth noticing - Saint-Petersburg and Moscow, which were always attractive to the migrants. Moreover, it's worth adding about regions which are no longer part of Russia: Poland which made the migration exchange between its regions; Transcaucasia mainly not participating in migration processes, excepting some new territorial acquisitions of Russian Empire and also Middle Asia taking part in migrations sluggishly. 
Figure 1. Typology of regions in 1897

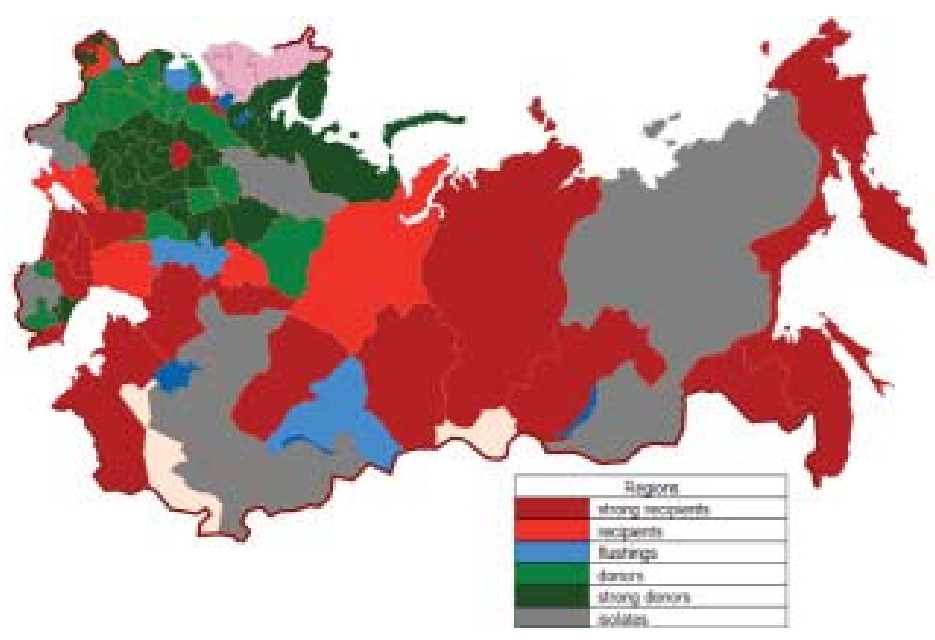

Source: Common set of results of the first all-population census (1905).

By 2010 the situation have changed cardinally (see figure 2). Moscow and Saint-Petersburg with their capital regions were still the most attractive for migrants. Furthermore, in certain view there remained the main giving centre from regions of European part which rapidly reduced its potential due to the aging of the population. The main changes affected regions of Ural, Siberia and Far East. Thus, Western and Eastern Siberia which had the same initial conditions and severe climate are now in different situations relatively to the domestic migrations. Eastern Siberia is rapidly losing population while gas and oil-producing western Siberia is one of the few attractive regions for domestic migrants. Far East during few last centuries was rather attractive for migrants but from 1980-s it has been giving the population either to European part either to the south of Russia, or the movements are carried out inside Far East to the 'north-south' (for example, to Primorie territory). The process of movements from regions of Siberia and Far East to European part of Russia was named 'Western drift'

Figure 2. Typology of regions in 2010

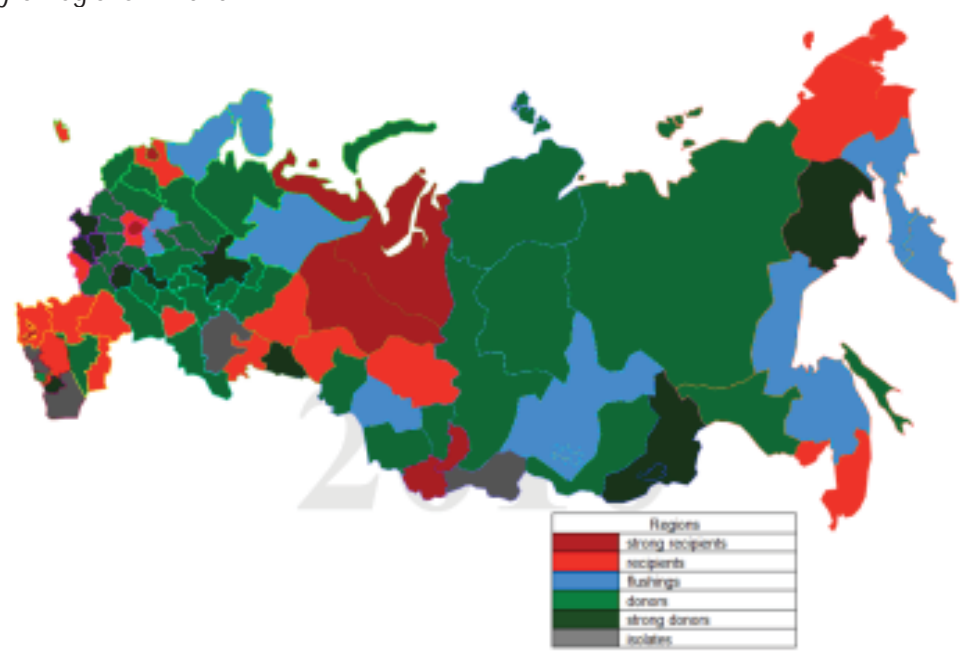

Source: The results of the population census of 2010 (2013). 
From all migration factors the flow of migrants to the most economically developed regions is the most stable in duration and force of influence. Agricultural colonization with the time changed to migration flows directing to the industrial centers and also to the opening up of regions with large stock of minerals (and with higher salaries). However, during the period after USSR collapse many regions of the new generation began to lose population due to the great reduction of income level caused by system crisis and breaching of economic relations, except regions of Western Siberia which became big centers of migrants attraction.

\section{Conclusion}

Rapid development of the economics, transport, beginning of demographic transition and appearing of redundant amount of rural population in the end of XIX century strengthened process of agricultural development of the regions of Siberia and Far East by the migrants from the European part of Russia. Moving to cities was also significant - temporary moving for seasonal work and for the permanent residence.

Census of 1926 recorded a continuation of development of the country outlying areas. However, major changes have taken place- the revolution and civil war have caused an outflow of natives of the major cities and capitals to other regions, which, however, wascompensatedbythegrowingurbanizationandtheinfluxofformerpeasantstothecities. The establishment of the soviet caused the complete cessation of migrationties with foreign countries.

Census of 1989 was the summing up of the migration processes that have occurred during soviet period. Just at this time there was industrial development of the regions of the Extreme North, West and East Siberia and many parts of the Far East. In the postwar period territory of the Kaliningrad region was populated. The traditional centers of attraction were Moscow and Leningrad.

Censuses of 2002 and 2010 fixed stable trend of movement from the regions of Siberia and Far East to Moscow capital region, regions of Russian South and in western and south direction inside this micro regions. New centers of migrants attraction appeared - gas and oil-producing regions of Western Siberia.

Migration processes are bright indicator of socioeconomic processes in the country and, in spite of many other factors (ethnic composition of the population, geographic position etc.), main part of migration flows is directed to the regions with economic advantages. Such as: free lands (till census of 1926), availability of industrial centers and large cities (till census of 1989), carrying out of capital functions, higher salary.

.In the history of Russian domestic migrations there were few waves of colonization of new, mostly marginal lands. They were developed in the imperial period and more actively in soviet time. However in the end of soviet period migration processes reversed. And with some minor exceptions the most active donators of migrants became those regions which were developed in the recent past. The main migration process on the turn of XX-XXI centuries was 'Western drift' -movement from Eastern part of Russia to Western part.

\section{References}

All-Union Population Census of 1926. (1930) Moscow: Publishing CSB USSR.

All-Union Population Census of 1989. The distribution of the population of union and autonomous republics, autonomous regions and districts and regions of the place of birth. Retrieved from http://demoscope.ru/weekly/ssp/sng_pob_89.php

Borodkin LI, Maksimov SV (1993) The peasant's migration in Russia and USSR in the first quarter of the XX century (Macroanalysis of structure of the migration flows). Otechestvennaya istoriya [History of Russia]. Number 5.

Brockhaus and Efron Encyclopedic Dictionary: In 86 volumes (82 tons and 4 add.). - St. Petersburg., 1890-1907.

Common set of results of the first all-population census, produced in 28 January 1897. (1905) St. Petersburg.

Karachurina LB (2004) Migration in Russia: regional analysis. Demoscope Weekly. Number 177 - 178. Retrieved from http://www.demoscope.ru/weekly/2004/0177/analit06.php

Lurie LY (1999) The times and Mores. Piterschiks in St. Petersburg. Neprikosnovenny zapas. Number 3 (5).

Mkrtchyan NV (2003) From Russia to Russia: from and where do internal migrants ride. Universe of Russia. Volume XII. Number 2.

Mkrtchyan NV (2004) "Western drift" of domestic migration. Otechestvenniye Zapiski. Number 4.

Moyseenko VM (1997) Migration of population in censuses of Russia and the USSR. Statistical Studies. Number 3.

Moyseenko VM (2004) Internal migration of the population. Moscow: Teis. 2004.

Moyseenko VM (2008) Essays in the study of the population migration in Russia in the second half of XIX - early XX century. Moscow: Teis.

Perevedentsev VI (1975) Methods of the migration study. Moscow: Nauka. [Science].

Perevedentsev VI (2010) Russia in the mirror of census. Migration in the rhythm of time. comp. Zayonchkovskaya JA. Moscow: MAKS Press. 2010. 
Politics of immigration and of naturalization in Russia: status and directions of development (2005) Ed. SN Gradirovsky M.: Foundation "Legacy of Eurasia".

Principles and Recommendations for Population and Housing Censuses (2009) UN Statistical Papers. Retrieved from http://unstats.un.org/unsd/censuskb20/Attachment457.aspx

Rybakovsky LL (1996) Russia and the new countries: migration exchange and its impact on the demographic dynamics. Moscow: ISPR RAS.

Skaterschikova EE (1996) Lifetime migration as a factor of territorial unity Russia. Geography. Number32.

Tarhov SA (2003) The historical evolution of the administrative-territorial and political division of Russia. Demoscope Weekly. Number 101 - 102. Retrieved from http://www.demoscope.ru/weekly/2003/0101/analit04.php

The population of Russia in 2002. The tenth annual demographic report (2004) Min. Ed. AG Vishnevsky, Moscow: University.

The results of the population census of 2002.The duration of living of the population in the place of permanent residence. Volume 10. Moscow: Russian Statistics. (2005) Official site of the National Population Census of 2002. Retrieved from http://www.perepis2002.ru/index.html?id=19

The results of the population census of 2010.The duration of living of the population in the place of permanent residence. Volume 8 . Moscow: Russian Statistics. (2013) Official site of the Rosstat. Retrieved from http://www.gks.ru/free_doc/new_site/ perepis2010/croc/perepis_itogi1612.htm

Tikhonov BV (1976) Resettlement in Russia in the second half of the XIX century (based on the 1897 census and statistics of the passports). Moscow: Nauka. [Science]. 